\title{
Uma abordagem preditiva da evasão na educação a distância a partir dos construtos da distância transacional
}

\author{
Jorge Luis Cavalcanti Ramos ${ }^{1}$ (Autor), Alex Sandro Gomes ${ }^{2}$ (Orientador) \\ ${ }^{1}$ Universidade Federal do Vale do São Francisco - Juazeiro - BA - Brasil \\ ${ }^{2}$ Centro de Informática - Universidade Federal de Pernambuco, Recife-PE, Brasil \\ jorge.cavalcanti@univasf.edu.br, asg@cin.ufpe.br
}

\section{Resumo}

O crescimento da Educação a Distância (EAD) tem sido apoiado por teorias para auxiliar o planejamento e a execução de cursos de maneira eficaz e eficiente. As pesquisas na área também refletem esse crescimento, à medida que buscam atenuar ou resolver problemas que surgem decorrentes dessa expansão, como por exemplo os altos índices de evasão ainda verificados na modalidade. Para a maioria das instituições que participaram do Censo Anual da EAD no Brasil em 2015, o grande obstáculo enfrentado tem sido a evasão nos cursos, quando para $40 \%$ das instituições pesquisadas, a taxa média de evasão foi entre $26 \%$ e $50 \%$ nos cursos totalmente ofertados a distância por essas instituições. Partindo de uma necessidade de renovação de teorias da EAD, bem como aplicá-las no sentido de auxiliar no enfrentamento nos desafios da modalidade, esta pesquisa enfocou a Teoria da Distância Transacional, proposta por Moore (1972, 1973, 1993, 2013). Foi sugerida uma nova abordagem para determinação dos seus construtos, com o propósito de aplicá-los em um processo de detecção precoce de alunos com tendências a evasão, em cursos superiores ofertados a distância. A utilização de técnicas de análise multivariada para a obtenção dos construtos da distância transacional teve a intenção de buscar uma abordagem distinta das atualmente verificadas na literatura. Essa determinação é feita, na maioria dos casos, utilizando questionários aplicados a alunos e professores. Também, as evidências na literatura apontam o uso de diversas técnicas de mineração de dados e aprendizagem de máquina na definição de modelos preditivos em contextos educacionais, com índices satisfatórios de acertos. A partir da obtenção dos componentes (variáveis) dos construtos da distância transacional, foi também definido e validado um modelo de previsão da evasão de alunos em cursos a distância, a partir desses componentes. Foram usados diversos algoritmos classificadores, sendo o classificador por regressão logística apresentado resultados mais relevantes quando comparados aos registrados pela literatura na área. A metodologia dos testes e as análises dos seus resultados permitiram concluir que um conjunto de variáveis representativas da distância transacional, quando incorporadas a um modelo preditivo de evasão de alunos, pode fornecer informações e subsídios para que seus atores possam tomar decisões e intervir no processo educacional de modo a buscar reduzir o risco de evasão de um ou de um grupo de alunos em EAD. Foi então desenvolvida uma aplicação com o modelo preditivo implementado, para testes com professores e tutores que atuam na EAD, sendo a mesma bem avaliada por esses usuários.

Referência: RAMOS, Jorge Luis Cavalcanti e GOMES, Alex Sandro. "Um Modelo Preditivo da Evasão dos Alunos na EAD a partir dos Construtos da Teoria da Distância Transacional". Anais do Simpósio Brasileiro de Informática na Educação. Vol. 28. No. 1. 2017. 